\title{
PENGARUH PELATIHAN DAN MOTIVASI KERJA TERHADAP KINERJA KERJA KARYAWAN PT ASIA MULTIDANA DI JAKARTA
}

\author{
Okky Pratama \\ Program Studi Magister Manajemen Universitas Tarumanagara \\ pratamaokky94@gmail.com
}

Masuk : 15-06-2019, revisi : 02-09-2019 diterima untuk diterbitkan : 03-09-2019

\begin{abstract}
This study was to detect the effect of training and motivation on employee performance studies in the limited partnership. This research was conducted with survey method and performed in 40 employees of PT Asia Multidana. The sampling technique used random sampling and testing techniques of data used in this study include tests of validity by factor analysis, reliability tests with Cronbach alpha, classical assumption test, multiple linear regression analysis, $t$ test to test and prove the hypothesis of the study. The data collected is tested for validity by factor analysis method and tested reliability with an alpha coefficient (Cronbach alpha), which is the result of all the data is valid and reliable. The results of the analysis and discussion show that: (1) training positively affect the performance of employees, (2) positive motivation does not affect the performance of the employee.
\end{abstract}

Abstrak : Penelitian ini adalah untuk mendeteksi pengaruh pelatihan dan motivasi terhadap kinerja kerja karyawan studi dalam kemitraan terbatas. Penelitian ini dilakukan dengan metode survei dan dilakukan di 40 karyawan PT Asia Multidana. Teknik pengambilan sampel yang dipakai metode acak dan teknik pengujian data yang digunakan dalam penelitian ini meliputi uji validitas dengan analisis faktor, reliabilitas tes dengan alpha cronbach, uji asumsi klasik, analisis regresi linier berganda, uji t untuk menguji dan membuktikan hipotesis penelitian. Data yang terkumpul untuk validitas diuji dengan metode analisis faktor dan diuji reliabilitas dengan koefisien alpha (alpha cronbach), dimana merupakan hasil seluruh data dinyatakan valid dan reliabel. Hasil dari analisis dan pembahasan menunjukkan bahwa: (1) pelatihan yang positif berpengaruh terhadap kinerja kerja karyawan, (2) motivasi kerja yang positif tidak berpengaruh terhadap kinerja kerja karyawan.

Keywords : Leadership, Motivation, Employee Performance

\section{PENDAHULUAN}

Kinerja seorang karyawan dalam sebuah perusahaan sangat dibutuhkan untuk mencapai prestasi kerja bagi karyawan itu sendiri dan untuk keberhasilan perusahaan. Iistilah kinerja berasal dari job performance atau actual performance yang berarti hasil kerja secara kualitas dan kuantitas yang ingin dicapai oleh seorang pegawai dalam melaksanakan tugasnya sesuai dengan tanggung jawab yang diberikan kepadanya (Mangkunegara, 2011). Karyawan yang memilki kualitas, kuantitas, dan ketepatan waktu merupakan karyawan yang hasil kerjanya dirasakan oleh perusahaan dan sangat besar manfaatnya bagi kelangsungan keberadaan perusahaan. Hasil kerja yang dicapai oleh seorang karyawan harus memberikan kontribusi yang penting bagi perusahaan.

Berdasarkan hasil observasi awal penulis, karyawan PT. Asia Multidana menyatakan permasalahan yang dihadapi PT. Asia Multidana adalah seringnya karyawan bekerja tidak sesuai dengan yang di harapkan perusahaan dan sering juga karyawan terlambat masuk kerja dan absen dalam bekerja, sehingga menyebabkan penurunan kinerja karyawan dan berdampak pada penurunan pendapatan Asia Multidana. Sebagai perusahaan swasta yang cukup besar dan 
terkenal, PT.Asia Multidana sudah seharusnya meningkatkan sumber daya manusia terutama memikirkan pentingnya peran pelatihan dan motivasi dalam menunjang kinerja karyawan, karena pelatihan merupakan kebutuhan yang diharapkan dapat meningkatkan kemampuan setiap karyawan untuk menunjang kinerja dan motivasi yang diberikan kepada karyawan sangatlah penting untuk kinerja karyawan, untuk itu perusahaan harus bisa memikiran kebutuhan dari karyawannya dan memotivasi setiap karyawannya.

\section{TELAAH KEPUSTAKAAN \\ Pelatihan}

Menurut Simamora (2004, p.344) pelatihan pegawai atau training adalah upaya sistematik perusahaan untuk meningkatkan segenap pengetahuan (knowledge), keterampilan (skill) dan sikap-sikap kerja (attitudes) para pegawai melalui proses belajar agar optimal dalam menjalankan fungsi dan tugas-tugas jabatannya. Dessler (2011, p.118) pelatihan kerja merupakan proses mengajarkan karyawan baru atau yang ada sekarang, keterampilan dasar yang mereka butuhkan untuk menjalankan pekerjaan mereka. Menurut Hasibuan (2011, p.101), tujuan pelaksanaan pelatihan adalah sebagai berikut:

1. Pekerjaan yang dilakukan karyawan lebih cepat dan baik.

2. Untuk mengembangkan keahlian, pengetahuan serta sikap karyawan sehingga pekerjaan dapat diselesaikan dengan baik.

3. Meningkatkan kualitas kerja, produktivitas, dan profit.

4. Tanggung jawab yang diharapkan lebih besar.

\section{Kinerja (Employee Performance)}

Menurut Hasibuan (2011, p.34) kinerja (prestasi kerja) adalah suatu hasil kerja yang dicapai seseorang dalam melaksanakan tugas-tugas yang dibebankan kepadanya yang didasarkan atas kecakapan, pengalaman, dan kesungguhan serta waktu. Dari beberapa pandangan mengenai pengertian kinerja menurut para ahli, maka disimpulkan bahwa kinerja karyawan adalah hasil kerja karyawan sebuah perusahaan untuk mencapai tujuan atau target yang telah ditentukan pada periode waktu tertentu. Menurut Anwar (2006, p.67) pengertian kinerja adalah hasil kerja secara kualitas dan kuantitas yang dicapai oleh seorang karyawan dalam melaksanakan tugasnya sesuai dengan tanggung jawab yang diberikannya.

\section{Motivasi (Motivation)}

Menurut Mangkunegara (2011, p.94) motivasi merupakan kondisi yang berpengaruh membangkitkan, mengarahkan, dan memelihara perilaku yang berhubungan dengan lingkungan kerja. Mathis dan Jackson (2006, p.89) mengatakan, motivasi merupakan hasrat di dalam seseorang menyebabkan orang tersebut melakukan suatu tindakan. Seseorang melakukan suatu tindakan untuk sesuatu hal dalam mencapai tujuan. Menurut Hasibuan (2011, p.143) menyarajab motivasi adalah pemberian daya penggerak yang menciptakan kegairahan kerja seseorang agar mereka mau bekerja sama, bekerja efektif dan terintegrasi dengan segala daya upaya untuk mencapai kepuasan.

\section{Hubungan Pelatihan dan Motivasi Kerja dengan Kinerja Kerja}

Hubungan antara pelaksanaan kegiatan pelatihan dengan peningkatan kinerja adalah sangat erat, dimana kegiatan pelatihan tersebut dapat meningkatkan kinerja (produktivitas) karyawan. Umumnya para perusahaan mempekerjakan para karyawan yang belum terlatih. Sama seperti pada umumnya, setiap orang pasti mengalami proses pembelajaran untuk menjadi lebih baik. Begitu juga dengan para karyawan yang harus dilatih untuk dapat menghadapi berbagai pekerjaan yang dijalaninya. Sebaiknya pelatihan diberikan oleh perusahaan kepada karyawannya secara berkesinambungan. Pelatihan yang diberikan secara berkala serta diikuti evaluasi pula, akan menghasilkan karyawan yang terlatih serta dapat memicu peningkatan 
kinerja karyawan. Selain pelatihan, penting bagi karyawan untuk memiliki motivasi dalam bekerja agar bisa menampilkan pekerjaan yang optimal bagi diri sendiri dan perusahaan, motivasi akan memberikan kesempatan kepada karyawan untuk menyalurkan ego individu dan memperkuat komitmen karyawan pada perusahaan, dan tentunya meningkatkan kinerja karyawan.

\section{METODOLOGI PENELITIAN}

Jenis penelitian yang digunakan dalam penelitian ini adalah penelitian deskriptif, karena bertujuan untuk menyajikan gambaran secara terstruktur, faktual, dan akurat mengenai faktafakta serta hubungan antara variabel yang akan diteliti. Penelitian ini menggunakan pendekatan kuantitatif yaitu pendekatan yang memerlukan bantuan perhitungan ilmu statistik. Metode pengumpulan data yang digunakan adalah metode survei, yang mengambil sampel satu populasi dan menggunakan kuesioner sebagai alat pengumpulan data primer. Dalam penelitian ini populasinya adalah karyawan PT. Asia Multidana 2016 yang pernah mengikuti pelatihan berjumlah 105 orang karyawan. Peneliti menggunakn teknik purposive sampling. Jumlah sampel yang akan diteliti dalam penelitian ini yaitu sebanyak 40 responden. Metode-metode analisis yang digunakan pada penelitian ini adalah teknik uji validitas dan reliabilitas, uji asumsi klasik yang terdiri dari uji normalitas, uji multikolinearitas, dan uji homoskedastisitas, analisis regresi berganda, dan teknik pengujian hipotesis yang terdiri dari uji parsial (uji t), uji signifikan simultan (uji F), dan koefisien determinasi $\left(\mathrm{R}^{2}\right)$. Data diproses dengan menggunakan SPSS ver. 21.0 untuk Windows.

\section{ANALISIS DAN BAHASAN TEMUAN Pembahasan}

Berdasarkan hasil pengujian validitas dan reliabilitas, diketahui bahwa semua variabel yang diuji bersifat valid dan reliabel. Setelah melalui uji validitas dan reliabilitas, data kemudian dianalisis menggunakan uji asumsi klasik terhadap model regresi yang terdiri dari uji normalitas, uji multikolinearitas, dan uji Homoskedastisitas. Berdasarkan ketiga uji asumsi klasik tersebut, diketahui model regresi dapat digunakan karena telah sesuai dengan persyaratan yaitu: 1) residual terdistribusi secara normal, 2) tidak terdapatnya gelaja multikolinearitas, dan 3) tidak terjadi Homoskedastisitas

Dalam melakukan analisis regresi berganda, dirumuskan persamaan regresi sebagai berikut: $\mathrm{KK}=0,851+0,530 \mathrm{PK}+0,117 \mathrm{MK}$. Dimana KK merupakan variabel dependen yaitu Kinerja Kerja (Y) dan variabel independen yang terdiri dari PK adalah Pelatihan Kerja $\left(\mathrm{X}_{1}\right)$, MK adalah Motivasi Kerja $\left(\mathrm{X}_{2}\right)$. Setelah mendapatkan rumus persamaan regresi, selanjutnya dilakukanlah pengujian hipotesis berupa uji t, uji F, dan uji koefisien determinasi $\left(\mathrm{R}^{2}\right)$.

Hasil pengujian hipotesis pertama menunjukkan bahwa terdapat pengaruh positif dan signifikan pelatihan kerja terhadap kinerja kerja. Hal ini diketahui dari hasil pengujian yang menunjukkan nilai signifikan pelatihan kerja $0,000<0,05$ dan nilai koefisien beta positif 0,640 . Hasil pengujian hipotesis kedua menunjukkan bahwa motivasi kerja tidak berpengaruh signifikan terhadap kinerja kerja. Hal ini diketahui dari hasil pengujian yang menunjukkan motivasi kerja memiliki nilai koefisien beta positif 0,171 dan nilai signifikan $0,170<0,05$.

Hasil pengujian hipotesis keempat menunjukkan bahwa pelatihan kerja dan motivasi kerja secara simultan memiliki pengaruh positif dan signifikan terhadap kepuasan pelanggan. $\mathrm{Hal}$ ini diketahui dari hasil pengujian $\mathrm{F}$ sebesar 19,626 > F tabel 2,70 dan nilai signifikan 0,000 $<0,05$. Hasil pengujian koefisien determinasi dalam penelitian ini adalah $51,5 \%$ yang menyatakan besarnya hubungan variabel independen terhadap variabel dependen. Sedangkan sisanya $48,5 \%$ merupakan hubungan dengan variabel lain yang tidak termasuk dalam permodelan. 


\section{KESIMPULAN DAN SARAN}

\section{Kesimpulan}

1. Penelitian ini membuktikan bahwa adanya pengaruh positif dan signifikan antara pelatihan kerja terhadap kinerja kerja karyawan PT Asia Multidana di Jakarta.

2. Penelitian ini membuktikan bahwa tidak adanya pengaruh yang signifikan antara motivasi kerja terhadap kinerja kerja karyawan PT Asia Multidana di Jakarta.

3. Penelitian ini membuktikan bahwa adanya pengaruh positif dan signifikan antara pelatihan kerja dan motivasi kerja secara simultan terhadap kinerja kerja karyawan PT Asia Multidana di Jakarta.

\section{Saran}

1. Pada hasil penelitian ini disimpulkan bahwa pelatihan kerja merupakan salah satu faktor dalam mempengaruhi kinerja kerja. Maka PT Asia Multidana harus memperhatikan pelatihan kerja para manajer dengan cara lebih mendekatkan diri lagi kepada karyawan dan membangun sistem interaksi yang kuat dengan pelanggannya.

2. Pada hasil penelitian ini disimpulkan bahwa motivasi kerja tidak mempengaruhi kinerja kerja. Maka diharapkan PT Asia Multidana mampu menciptakan motivasi kerja yang lain dan terus mengupayakan pelayanan yang terbaik bagi karyawan dengan memberi fasilitas yang memadai dan menjaga integritas karyawannya, sehingga karyawan percaya dan tetap nyaman dalam bekerja.

3. Metode pengambilan sampel yang digunakan yaitu non probability sampling dengan teknik convenience sampling yang mempunyai kelemahan dalam mempresentasikan populasi yang ada karena pemilihan sampel berdasarkan pertimbangan dari peneliti.

4. Penelitian ini bersifat Cross Sectional Study dimana hanya mengambil suatu waktu tertentu saja.

\section{DAFTAR KEPUSTAKAAN}

Desler, Gary, (2011). Personal Management, Virginia : Reston Publishing Company Inc.

Anwar, Winardi. (2006). Motivasi Dan Pemotivasian Dalam Manajemen, Jakarta, Bina Aksara.

Mathis dan Jackson. (2012). Manajemen Sumber Daya Manusia, Jakarta : Erlangga

Hasibuan, Malayu S.P. (2011). Manajemen Sumber Daya Manusia. Jakarta : Bumi Aksara.

Mangkunegara, A. A. Anwar Prabu. (2011). Manajemen Sumber Daya Manusia Perusahaan. Bandung : PT Remaja Rosdakarya.

Simamora, Bilson. (2004). Remarketing for Business Recovery, Sebuah Pendekatan Riset. Jakarta: Gramedia PU. 